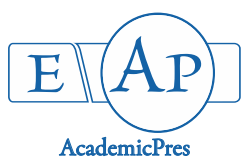

Dada EO et al. (2021)

Notulae Scientia Biologicae

Volume 13, Issue 4, Article number 10962

DOI: $10.15835 / \mathrm{nsb} 13410962$

Research Article

\title{
Effluent from local palm oil mill refinery in Nigeria is excessively oily and potentially genotoxic
}

\section{Ebenezer O. DADA ${ }^{1 *}$, Mutiu O. SIFAU ${ }^{1}$, Oreoluwa M. GBEGBE ${ }^{1}$ Haolat O. IBRAHIM ${ }^{2}$, Olushola O. ADEFILA ${ }^{2}$}

\author{
${ }^{1}$ University of Lagos, Faculty of Science, Department of Cell Biology and Genetics, Akoka, Yaba, Lagos State, Nigeria; \\ eodada@unilag.edu.ng(*correspondingauthor);osifau@unilag.edu.ng; sunkanmiforsuccess@yahoo.com \\ ${ }^{2}$ Federal Polytechnic, Department of Science Laboratory Technology, Offa, Kwara State, \\ Nigeria;ibrahimho234@gmail.com; ooadefilla@gmail.com
}

\begin{abstract}
In spite of the fact that the informal, local mills in countries like Nigeria constitute a major portion of the palm oil refinery, adequate attention has not been paid to the quality of the palm oil mill effluent (POME) they generate. In this study, therefore, the physicochemical properties and genotoxic potential of POME generated by a local mill in Nigeria were investigated using the methods prescribed by the American Public Health Association and Allium cepa chromosomal assay, respectively. In addition to the presence of trace/toxic metals $(\mathrm{Zn}, \mathrm{Pb}, \mathrm{Cd}, \mathrm{Cr}, \mathrm{Cu})$ and high biochemical oxygen demand, POME contained a very high oil and grease concentration of $10,500 \mathrm{mg} \mathrm{L}^{-1}$ as against the maximum limit of $25 \mathrm{mg} \mathrm{L}^{-1}$ prescribed in the Environmental Management Guideline for the Palm Oil Industry. Mitotic activities in A. cepa roots exposed to POME showed that the number of dividing cells and percentage mitotic index generally decreased with increasing POME concentrations. The major chromosomal aberrations induced by POME were sticky, C-mitosis, bridged anaphase, vagrant, and attached chromosomes. However, no chromosomal aberrations were observed in onion roots exposed to water (control). These results indicate that the local refinery from where the POME was obtained is inefficient at recovering oil from palm fibre. The effluent generated by the mill is also a potential pollutant capable of inducing genotoxic and other adverse effects. These results may be typical of many more local palm oil refineries who use mainly manual methods to extract oil from oil palm fruits.
\end{abstract}

Keywords: chromosomes; cytotoxicity; mitosis; pollutants; POME

\section{Introduction}

The oil palm industry is a major agro-based business in Africa, especially West Africa where oil palm trees are found both in the wild and in plantations (Eze et al., 2013). In Nigeria, there are a number of corporate palm oil refineries, but the business of palm oil extraction is dominated by the local, small scale and peasant farmers (Orji et al., 2006) who use mainly manual methods to extract oil from oil palm fruits.

Palm oil processing generates a number of waste by-products, such as empty fruit bunches, oil palm shell, palm fibre and palm oil mill effluent (POME) (Rupani et al., 2010; Otti et al., 2014). Of these wastes, POME

Received: 02 May 2021. Received in revised form: 21 Oct 2021. Accepted: 22 Oct 2021. Published online: 02 Nov 2021.

From Volume 13, Issue 1, 2021, Notulae Scientia Biologicae journal uses article numbers in place of the traditional method of continuous pagination through the volume. The journal will continue to appear quarterly, as before, with four annual numbers. 
is considered the most environmentally harmful, when discharged untreated (TDIW, 1997; Rupani et al., 2010; Madaki and Seng, 2013). POME is the liquid waste that comes from the sterilization and clarification sections of the oil palm milling process. It is composed of $4-5 \%$ solids (mainly organic), $0.5-1 \%$ residual oil, and about $95 \%$ water containing high concentration of organic nitrogen (Onyia et al., 2001). The processing stages involved in the extraction of oil from oil palm fruit in corporate and local mills are similar to a large extent. However, local milling of palm oil is relatively longer and laborious.

In local milling, palm fruit bunches are quartered (cut into four) and left overnight for easy separation of nuts from the spikelet. The fruits are boiled for about 1-2 hours, pounded in a mortar or macerated with the feet in a container. Water is added into the boiled, macerated fruits, and the mixture is properly mixed together. All the nuts are thereafter carefully removed from the mixture. The fibres are then thoroughly and carefully shaken over in the sludge, until oily foam comes up to the surface of the sludge. The oily foam is carefully collected from the surface into a container until the operation is completed, when there is no more foam formation. The foam is later boiled for about 30 to 40 minutes. Clean edible oil is collected on the surface leaving the sludge at the bottom. Sometimes the remnant oil in the sludge pit is recovered and mixed with fibre to make a fire-starting cake. The sludge that is eventually left is the POME. The resulting POME is recycled, or poured onto the surrounding water, bush, or soil, depending on the location of the refinery.

While corporate mills use large volumes of water and generate correspondingly large volumes of POME, local, small-scale mills release relatively less volumes of POME, because the POME generated is often reused, probably to recover more oil (Ohimain et al., 2012), or possibly due to limited water availability. Most times, when POME generated from the local mills are discarded, they are discharged, with little or no treatment (Okwute and Isu, 2007).

Many research works have evaluated the environmental burdens created by POME (Okwute and Isu, 2007; Igwe and Onyeagbado, 2007; Rupani et al., 2010; Ohimain et al., 2012; Syirat et al., 2014; Dada et al., 2018). Most of these studies are however centred on the observed harmful physico-chemical properties of POME generated by corporate palm oil refineries. This is in spite of the fact that the informal, local, small-scale mills in countries like Nigeria constitute a major portion of the palm oil refinery. This study therefore aimed to assess the physicochemical properties and genotoxic potential of POME obtained from a local mill in Nigeria.

\section{Materials and Methods}

\section{Collection of test samples}

The POME used for this study was obtained from a local, small-scale refinery in South Western State of Nigeria (Figures 1 and 2). POME was collected in a 10-litre high density plastic container and transported to the laboratory, where it was refrigerated at about $4{ }^{\circ} \mathrm{C}$ during the period of the study. The $A$. cepa (onions/onion bulbs) used for the study were procured from Bariga market in Lagos, Nigeria. The onions were sun-dried for two weeks, after which the dry ones were selected for the test.

\section{Physicochemical analyses of POME}

POME samples were analysed for physicochemical properties ( $\mathrm{pH}, \mathrm{DO}, \mathrm{BOD}, \mathrm{COD}$, suspended solids, total nitrogen, oil and grease, metals $(\mathrm{Pb}, \mathrm{Zn}, \mathrm{Cd}, \mathrm{Cu}, \mathrm{Cr})$ using the methods prescribed by the American Public Health Association (APHA) (1998). Some results of the physicochemical analyses were compared with the limits contained in the Environmental Management Guideline for the Palm Oil Industry published by the Thailand Department of Industrial Works (TDIW, 1997); this was the only readily available guideline specifically released for the palm oil industry. 


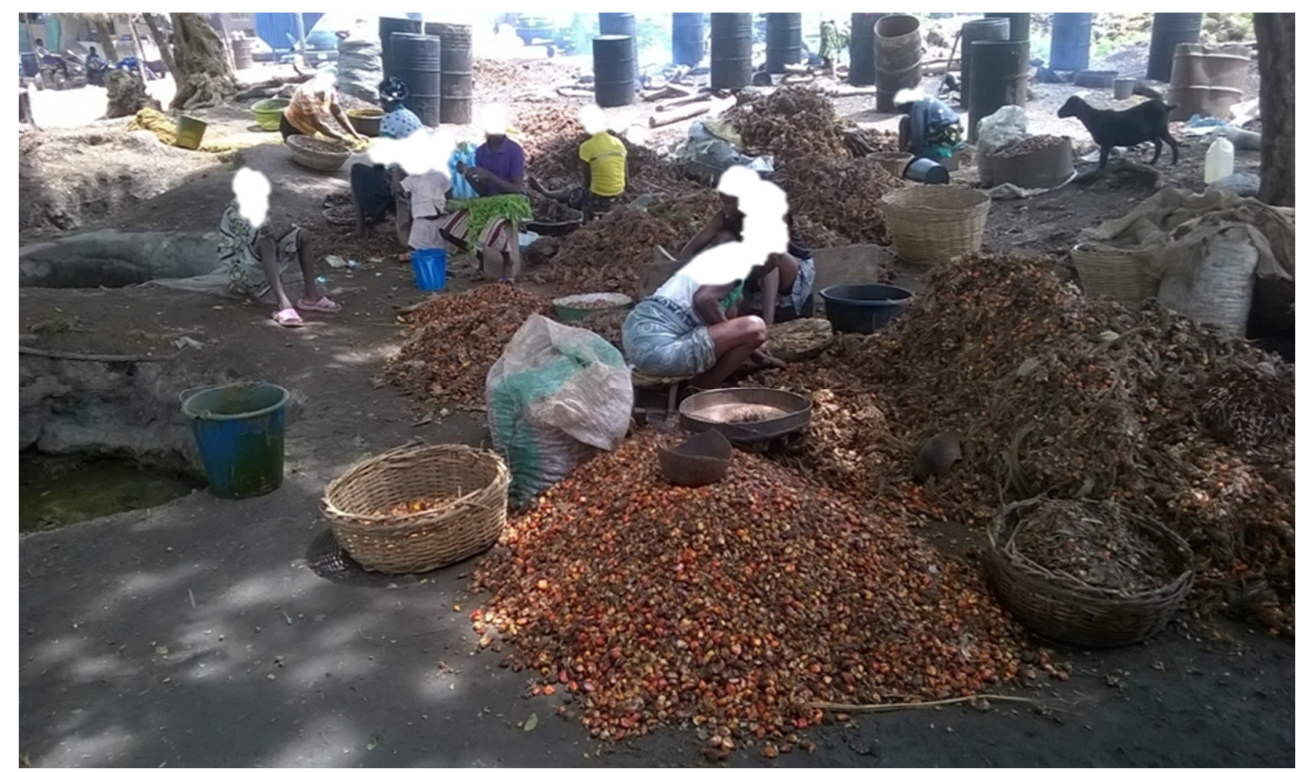

Figure 1. Processing of palm fruit in the local refinery from where POME was collected

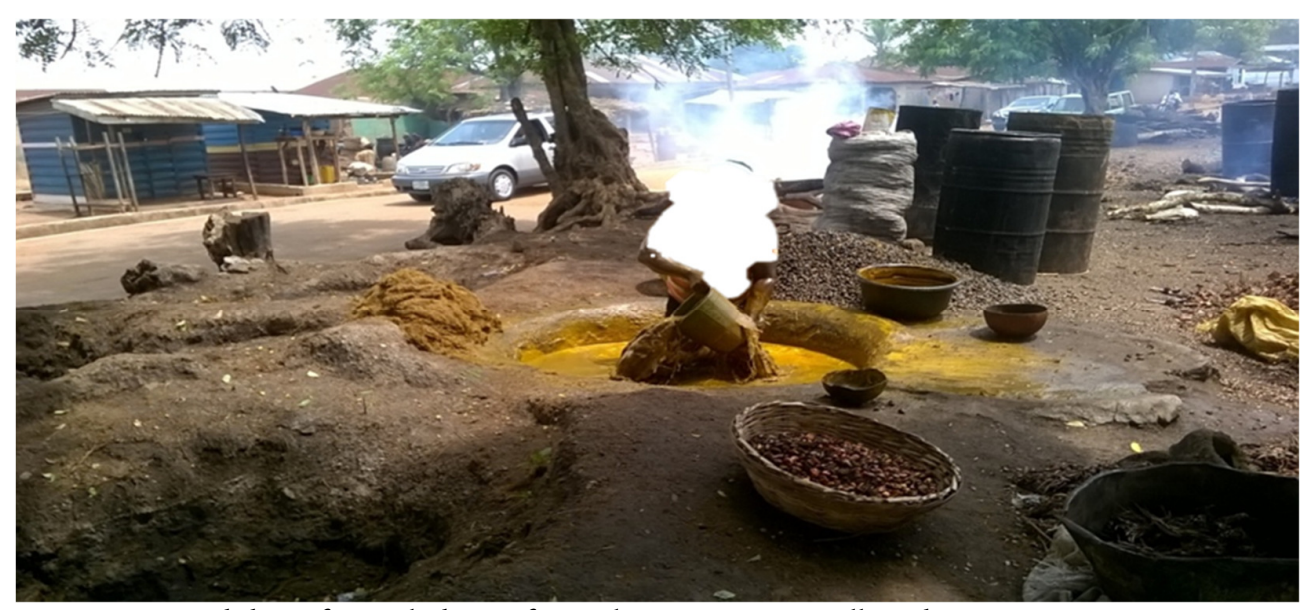

Figure 2. Ground-dug refining sludge pit from where POME was collected

To analyse the metals, $100 \mathrm{~mL}$ of POME sample was digested by heating with concentrated $\mathrm{HNO}_{3}$ until the volume was reduced to $3-5 \mathrm{~mL}$. This volume was made up to $10 \mathrm{~mL}$ with $0.1 \mathrm{~N} \mathrm{HNO}_{3}$. The concentration of the metal was estimated by using an Atomic Absorption Spectrophotometer (Perkin Elmer Analyte A 200 model).

\section{Procedure for A. cepa assay}

The Allium test was adapted from Fiskesjo (1997), Adegbite and Olorode (2002), Dada et al. (2018). The outer scales and brownish bottom plates of sun-dried onion bulbs were carefully removed, leaving the ring of primordial root intact. The peeled bulbs were placed in de-chlorinated tap water during the cleaning procedure to prevent the primordia from drying up. Graduated concentrations of POME $(10 \%, 20 \%, 30 \%$, $100 \%$ ) were prepared by diluting with the appropriate volumes of de-chlorinated water. The peeled onion bulbs were first grown in de-chlorinated tap water at room temperature for 24 hours. After 24 hours, the bulbs were transferred to the prepared concentrations of POME $(10 \%, 20 \%, 30 \%, 100 \%)$. The onions grown in water only served as the control. The test substrates were changed daily throughout the test period. Six onion bulbs were set up for each concentration, out of which the best five were selected for evaluation. 
To determine root growth inhibition by POME, the root lengths of the onions exposed to each POME concentration, and the ones exposed to water (control) were measured at 24, 48, and 72 hours of exposure. Mean root length, percentage root length, and percentage root length inhibition were calculated according to the following Equations 1, 2, and 3, respectively.

$$
\begin{aligned}
& \text { Mean root length }(\mathrm{cm})=\frac{\text { Summation of root lengths }}{\text { Total number of roots }} \\
& \text { Percentage root length }=\frac{\text { mean root length in test solution }}{\text { mean root length in control }} \times 100 \\
& \text { Percentage }(\%) \text { root length inhibition }=\frac{\text { mean root length in control-mean root length in test solution }}{\text { mean root length in control }} \times 100
\end{aligned}
$$

\section{Cytological assessment}

Chromosomal aberration assessment was carried out by the squash technique for onion root as described by Adegbite and Olorode (2002). At the end of the exposure periods, the roots of onion bulbs with the best growth at each concentration were removed with forceps and fixed in 1:3 aceto-alcohol. Cells for cytological studies were prepared from the root tip meristem containing actively growing cells. One root tip was squashed on each slide, and stained with acetocarmine for 10 minutes. Cover slips were carefully lowered onto the slide, to exclude air bubbles. To prevent the possible drying out of the preparation, the cover slips were sealed onto the slides with clear fingernail polish. Each prepared slide was viewed under the 40x objective lenses of the light microscope (Leica 2000 phase contrast microscope) to observe its mitotic stages. Mitotic index and percentage mitotic index were calculated according to Equations 4 and 5, respectively.

$$
\begin{aligned}
& \text { Mitotic Index }=\frac{\text { Number of dividing cells }}{\text { Total number of cells counted }} \times 100 \\
& \text { Percentage Mitotic Index }=\frac{\text { Mitotic index in control-mitotic index in test solution }}{\text { Mitotic index in control }} \times 100
\end{aligned}
$$

Scoring of chromosomal aberrations was taken from 5 microscopic fields for each of the POME concentrations. Percentage chromosomal aberration was calculated according to Equation 6 below.

$$
\text { Percentage aberration }=\frac{\text { Total number of chromosomal aberrations }}{\text { Total number of dividing cells }} \times 100
$$

\section{Statistical analysis}

The data generated were analysed using one-way analysis of variance (ANOVA). Mean differences were compared for level of significance using the Least Significant Difference (LSD) post hoc. All statistical analyses were carried out using the Statistical Package for Social Sciences (version 22.0).

\section{Results}

\section{Physicochemical characteristics of POME}

The physicochemical parameters of POME are presented in Table 1, along with the limits set in the Environmental Management Guideline for the Palm Oil Industry, published by TDIW. The $\mathrm{pH}$ of the POME was 5.9 while the turbidity, alkalinity, and acidity levels were $491.0 \mathrm{NTU}, 296.0 \mathrm{mg} \mathrm{L}^{-1}$, and $349.2 \mathrm{mg} \mathrm{L}^{-1}$, respectively. The concentrations of phosphate and potassium in the POME were $198.60 \mathrm{mg} \mathrm{L}^{-1}$ and 2119.51 $\mathrm{mg} \mathrm{L}^{-1}$, respectively. The total nitrogen in the POME was $711.95 \mathrm{mg} \mathrm{L}^{-1}$ while the oil and grease content were 
$10,500.00 \mathrm{mg} \mathrm{L}^{-1}$. The concentrations of $\mathrm{Pb}, \mathrm{Cu}, \mathrm{Zn}$, and $\mathrm{Cd}$ in POME were $0.04 \mathrm{mg} \mathrm{L}^{-1}, 0.66 \mathrm{mg} \mathrm{L}^{-1}, 2.89 \mathrm{mg}$ $\mathrm{L}^{-1}$, and $0.01 \mathrm{mg} \mathrm{L}^{-1}$, respectively.

Table 1. Physicochemical properties of POME

\begin{tabular}{|c|c|c|}
\hline \multirow{2}{*}{ Qualities } & \multicolumn{2}{|c|}{ Concentrations } \\
\hline & POME & TDIW limits \\
\hline \multicolumn{3}{|c|}{ Physical } \\
\hline $\mathrm{pH}$ & 5.9 & $5.5-9.0$ \\
\hline Turbidity (NTU) & 491.0 & $<1,000$ \\
\hline Electrical conductivity $\mu \mathrm{S} \mathrm{cm}^{-3}$ & $2,568.0$ & $\mathrm{Na}$ \\
\hline Total dissolved solids $\mathrm{mg} \mathrm{L}^{-1}$ & $1,284.0$ & $\mathrm{Na}$ \\
\hline \multicolumn{3}{|l|}{ Chemical } \\
\hline Oil and grease $\mathrm{mg} \mathrm{L}^{-1}$ & $10,500.0$ & $<25$ \\
\hline Total alkalinity $\mathrm{mg} \mathrm{L}^{-1}$ & 296.00 & $\mathrm{Na}$ \\
\hline Total acidity $\mathrm{mg} \mathrm{L}^{-1}$ & 349.2 & $\mathrm{Na}$ \\
\hline Biological oxygen demand (BOD) $\mathrm{mg} \mathrm{L}^{-1}$ & 125.0 & $<100$ \\
\hline Chemical oxygen demand (COD) $\mathrm{mg} \mathrm{L}^{-1}$ & $1,786.0$ & $<1000$ \\
\hline Dissolved Oxygen (DO) $\mathrm{mg} \mathrm{L}^{-1}$ & 3.9 & $\mathrm{Na}$ \\
\hline Chloride $\mathrm{mg} \mathrm{L}^{-1}$ & 441.0 & $\mathrm{Na}$ \\
\hline Total nitrogen $\mathrm{mg} \mathrm{L}^{-1}$ & 711.95 & $<50$ \\
\hline Potassium mg L $\mathrm{L}^{-1}$ & $2,119.51$ & $\mathrm{Na}$ \\
\hline Phosphate $\mathrm{mg} \mathrm{L}^{-1}$ & 198.60 & $\mathrm{Na}$ \\
\hline \multicolumn{3}{|c|}{ Metals } \\
\hline Zinc $\mathrm{mg} \mathrm{L}^{-1}$ & 2.89 & $\mathrm{Na}$ \\
\hline Lead $\mathrm{mg} \mathrm{L}^{-1}$ & 0.04 & $\mathrm{Na}$ \\
\hline Cadmium mg L ${ }^{-1}$ & 0.01 & $\mathrm{Na}$ \\
\hline Chromium mg L ${ }^{-1}$ & 0.18 & $\mathrm{Na}$ \\
\hline Copper mg L ${ }^{-1}$ & 0.66 & $\mathrm{Na}$ \\
\hline
\end{tabular}

POME = Palm oil mill effluent; TDIW = Thailand Department of Industrial Works (1997); $\mathrm{Na}=$ not available.

Effect of POME on the root growth of A. cepa

POME produced inhibitory effects on the root growth of $A$. cepa at $20 \%, 30 \%$, and $100 \%$ concentrations, but promoted root growth at $10 \%$ concentration. The highest inhibitory effects were produced at 72 hours of exposure while the lowest inhibitory effects were produced at 24 hours of exposure. Generally, root growth inhibitory effects increased with rising concentrations, especially at 48 and 24 hours of exposure. POME of $30 \%$ concentration produced the highest root growth inhibitory effects of $55.09 \%$ at 72 -hour of exposure. On the other hand, POME of $10 \%$ concentration promoted root growth to the tune of $7.23 \%$ at $24-$ hour of exposure (Table 2).

\section{Mitotic activity in $A$. cepa exposed to different concentrations of POME}

The mitotic activities in $A$. cepa roots exposed to POME showed that the numbers of dividing cells and percentage mitotic index generally decreased with increasing POME concentrations. In most cases, especially at 24-hour and 72-hour of exposure, the percentage mitotic inhibition increased with rising POME concentrations. The highest mitotic inhibition of $78.28 \%$ was induced by $100 \%$ POME concentration, at 72 hour of exposure. The least mitotic inhibition of $57.96 \%$ was also induced by $100 \%$ POME concentration, but at 48 -hour of exposure (Table 3). 
Table 2. Effect of POME on the root growth of $A$. cepa

\begin{tabular}{|l|c|c|c|c|c|c|c|c|c|}
\hline \multirow{2}{*}{ PC } & \multicolumn{3}{|c|}{ Mean root growth $(\mathbf{c m})$} & \multicolumn{3}{c|}{ \% Root growth } & \% Root growth inhibition \\
\cline { 2 - 10 } & 24hrs & 48hrs & 72hrs & 24hrs & 48hrs & 72hrs & 24hrs & 48hrs & 72hrs \\
\hline Ctr (0\%) & $0.83 \pm 0.30$ & $1.65 \pm 0.35$ & $1.67 \pm 0.38$ & 100.00 & 100.00 & 100.00 & 00.00 & 00.00 & 00.00 \\
\hline $\mathbf{1 0 \%}$ & $0.89 \pm 0.30$ & $1.29 \pm 0.45$ & $1.29 \pm 0.23$ & 107.23 & 78.18 & 77.25 & $-7.23 \#$ & 21.82 & 22.75 \\
\hline $\mathbf{2 0 \%}$ & $0.79 \pm 0.16$ & $0.80 \pm 0.25$ & $0.80 \pm 0.19$ & 95.18 & 48.48 & 47.90 & 4.82 & 51.52 & 52.10 \\
\hline $\mathbf{3 0 \%}$ & $0.70 \pm 0.24$ & $0.75 \pm 0.07$ & $0.75 \pm 0.16$ & 84.34 & 45.45 & 44.91 & 15.66 & 54.55 & 55.09 \\
\hline $\mathbf{1 0 0 \%}$ & $0.77 \pm 0.12$ & $0.77 \pm 0.21$ & $0.77 \pm 0.28$ & 92.77 & 46.67 & 45.29 & 7.23 & 52.69 & 53.89 \\
\hline
\end{tabular}

Table 3. Mitotic activity in $A$. cepa exposed to different concentrations of POME

\begin{tabular}{|c|c|c|c|c|c|c|c|c|c|c|c|c|}
\hline \multirow[t]{2}{*}{ PC } & \multicolumn{3}{|c|}{$\begin{array}{c}\text { Total cells } \\
\text { counted }\end{array}$} & \multicolumn{3}{|c|}{$\begin{array}{c}\text { Number of } \\
\text { dividing cells }\end{array}$} & \multicolumn{3}{|c|}{$\begin{array}{l}\text { \% Mitotic } \\
\text { index }\end{array}$} & \multicolumn{3}{|c|}{$\begin{array}{l}\text { \% Mitotic } \\
\text { inhibition }\end{array}$} \\
\hline & $24 \mathrm{hrs}$ & $48 \mathrm{hrs}$ & $72 \mathrm{hrs}$ & $24 \mathrm{hrs}$ & $48 \mathrm{hrs}$ & $72 \mathrm{hrs}$ & $24 \mathrm{hrs}$ & 48hrs & $72 \mathrm{hrs}$ & $24 \mathrm{hrs}$ & $48 \mathrm{hrs}$ & $72 \mathrm{hrs}$ \\
\hline $\operatorname{Ctr}(0 \%)$ & 500 & 500 & 500 & 126 & 98 & 90 & 25.20 & 19.60 & 18.00 & 00.00 & 00.00 & 00.00 \\
\hline $10 \%$ & 485 & 473 & 469 & 43 & 22 & 31 & 8.87 & 4.65 & 6.61 & 64.80 & 76.28 & 63.28 \\
\hline $20 \%$ & 481 & 468 & 464 & 39 & 27 & 26 & 8.11 & 5.77 & 5.60 & 67.82 & 70.56 & 68.87 \\
\hline $30 \%$ & 476 & 463 & 459 & 33 & 32 & 21 & 6.93 & 6.91 & 4.58 & 72.50 & 64.75 & 74.56 \\
\hline $100 \%$ & 465 & 449 & 435 & 27 & 37 & 17 & 5.81 & 8.24 & 3.91 & 76.94 & 57.96 & 78.28 \\
\hline
\end{tabular}

PC = POME concentration; $c$ cr $=$ control; hrs $=$ hours

\section{Chromosomal aberrations induced by POME}

POME induced chromosomal aberrations in $A$. cepa roots, but no aberration was observed in $A$. cepa exposed to water (control). The major aberrations induced were sticky, C-mitosis, bridged anaphase, vagrant, and attached chromosomes. Sticky and bridged chromosomes were the most frequent, recording a total of 78 and 52, respectively. Onions exposed to $10 \%$ POME concentration recorded the highest total aberration and highest percentage aberration of 61 and $63.54 \%$, respectively. The lowest percentage aberration of $45.80 \%$ was recorded by onions exposed to POME of $30 \%$ concentration (Table 4). Figure 3 shows representative normal and aberrant dividing cells.

Table 4. Major chromosomal aberrations induced in $A$. cepa root cells exposed to different concentrations of POME

\begin{tabular}{|c|c|c|c|c|c|c|c|c|c|c|c|c|c|c|c|c|c|}
\hline \multirow{3}{*}{ PC } & \multicolumn{17}{|c|}{ Chromosomal aberration type } \\
\hline & \multicolumn{3}{|c|}{ Sticky } & \multicolumn{3}{|c|}{ C-mitosis } & \multicolumn{3}{|c|}{$\begin{array}{l}\text { Bridged } \\
\text { anaphase }\end{array}$} & \multicolumn{3}{|c|}{ Vagrant } & \multicolumn{3}{|c|}{ Attached } & \multirow{2}{*}{$\begin{array}{c}\text { Total } \\
\text { Abr }\end{array}$} & \multirow{2}{*}{$\begin{array}{c}\% \\
\mathrm{Abr}\end{array}$} \\
\hline & $\begin{array}{l}24 \\
\text { hrs }\end{array}$ & $\begin{array}{l}48 \\
\mathrm{Hr}\end{array}$ & $\begin{array}{l}72 \\
\mathrm{hr}\end{array}$ & $\begin{array}{l}24 \\
\mathrm{hr}\end{array}$ & $\begin{array}{l}48 \\
\mathrm{hr}\end{array}$ & $\begin{array}{l}72 \\
\mathrm{hr}\end{array}$ & $\begin{array}{l}24 \\
\mathrm{hr}\end{array}$ & $\begin{array}{l}48 \\
\mathrm{hr}\end{array}$ & $\begin{array}{l}72 \\
\mathrm{hr}\end{array}$ & $\begin{array}{l}24 \\
\mathrm{hr}\end{array}$ & $\begin{array}{l}48 \\
\mathrm{hr}\end{array}$ & $\begin{array}{l}72 \\
\mathrm{hr}\end{array}$ & $\begin{array}{l}24 \\
\mathrm{hr}\end{array}$ & $\begin{array}{l}48 \\
\mathrm{hr}\end{array}$ & $\begin{array}{l}72 \\
\mathrm{hr}\end{array}$ & & \\
\hline $10 \%$ & 8 & 7 & 9 & 2 & 2 & 0 & 6 & 5 & 5 & 4 & 4 & 3 & 2 & 2 & 2 & 61 & 63.54 \\
\hline $20 \%$ & 9 & 6 & 6 & 1 & 0 & 0 & 6 & 4 & 3 & 4 & 4 & 2 & 2 & 3 & 3 & 53 & 57.61 \\
\hline $30 \%$ & 7 & 7 & 5 & 3 & 0 & 0 & 5 & 4 & 3 & 3 & 3 & 2 & 3 & 2 & 2 & 49 & 45.80 \\
\hline $100 \%$ & 5 & 5 & 4 & 0 & 1 & 0 & 4 & 4 & 3 & 3 & 2 & 4 & 2 & 2 & 1 & 40 & 49.38 \\
\hline Total & & $\begin{array}{c}\text { Stick } \\
78\end{array}$ & & & $\begin{array}{c}\text { mit } \\
9\end{array}$ & & & $\begin{array}{l}\text { ridg } \\
52\end{array}$ & & & $\begin{array}{c}\text { agra } \\
38\end{array}$ & & & 26 & & 203 & \\
\hline
\end{tabular}

$\mathrm{PC}=$ POME concentration; $\mathrm{Abr}=$ aberration; $\mathrm{hr}=$ hour; the differences in total aberrations induced by different POME concentrations are not significant $(\mathrm{p}>0.05)$. 


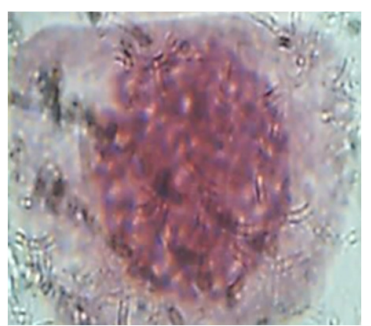

(a)

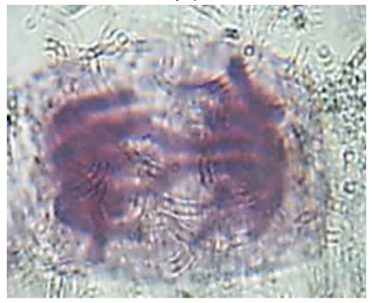

(d)

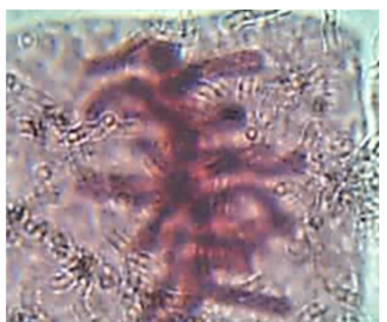

(b)

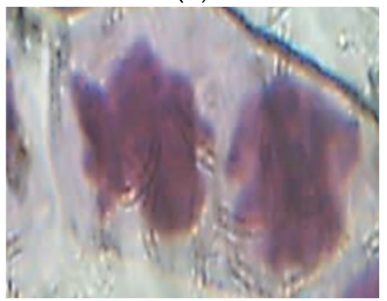

(e)

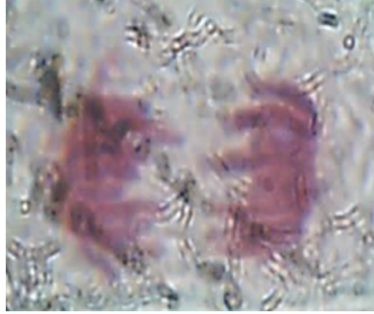

(c)

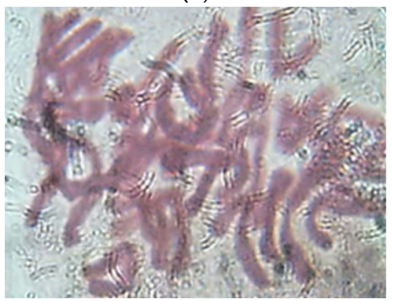

(f)

Figure 3. Photomicrographs of some representative normal and aberrant dividing cells $\mathrm{a}=$ normal prophase $\mathrm{b}=$ normal metaphase; $\mathrm{c}=$ normal anaphase; $\mathrm{d}=$ bridged chromosomes; $\mathrm{e}=$ sticky chromosomes; $\mathrm{f}=$ vagrant chromosomes.

\section{Discussion}

Physicochemical analyses, including heavy metal characterization, are a common method of assessing toxicity. In this study, many physicochemical parameters of POME, including electrical conductivity, total dissolved solids, BOD, COD, potassium levels were high, and in some cases, far higher than the limits contained in the Environmental Management Guideline for the Palm Oil Industry, released by TDIW (1997). Moreover, when compared with previous studies (Ohimain et al., 2012; Dada et al., 2018), most of the physicochemical parameters were relatively higher. A particular instance is the oil and grease concentration which was over 4,000 folds higher than the limit of $25 \mathrm{mg} \mathrm{L}^{-1}$ set by TDIW. A major implication of the very high oil and grease concentration is that local palm oil milling is inefficient at recovering oil from palm fibre. With such high concentrations of oil and grease, and other polluting parameters in POME, it may be assumed that local palm oil milling is potentially unsustainable, as it constitutes a threat to the health of the environment.

When oil and grease polluted effluent, like the POME evaluated in this study, is discharged into a water body, it may create health issues and lead to emission of odour due to delayed eutrophication. In addition, the oil and grease components of a wastewater can form a layer on the surface of water, leading to reduced DO and increased COD and BOD, all of which disrupt ecosystem balance, and threaten aquatic life. Oil and greaseladen wastewater may also be unsuitable for farm irrigation as it can block irrigation systems (Sahu et al., 2007; Travis et al., 2008; Khwakaram, 2016). If discharged on land, oil and grease polluted wastewater can block soil pores, leading to anaerobic conditions. Soil anaerobic condition can in turn lead to unpleasant odour, inhibited plant growth, and degraded soil quality (Travis et al., 2008). High oil and grease concentration decreases the effectiveness and efficiency of wastewater treatment processes (McPhail, 2015).

The low mitotic index, high mitotic inhibition, and aberrant chromosomes observed in this study are indications that the POME generated by the local mill is mitodepressive, cytotoxic, and genotoxic. These effects likely resulted from the high pollutant loads in the POME. Mitotic index is considered a reliable assessment of the presence of cytotoxic pollutants in the environment (Kaymak and Goc-Rasgele, 2009; Radic et al., 2010). The low mitotic index and high mitotic inhibition were likely brought about by the suppression or disruption of DNA replication by pollutants, such as metals, contained in POME (Sudhakar et al., 2001). Metals are capable of inducing decreased mitotic index by interacting with DNA to bring about cell cycle disruption and 
chromatin dysfunction (Glinska et al., 2007). Sticky chromosome, which was the most frequently observed aberration, results from chromatin dysfunction, chromatid breaks, and spindle failure, which suggests the presence of clastogens (agents capable of inducing chromosome/chromatid breaks) and aneugens (agents capable of inducing chromosome/chromatid gain or loss) in the effluent (Leme and Marin-Morales, 2009). Sticky chromosomes lead to abnormal uncoiling of chromosomes between anaphase and telophase (Qian et al., 2006). Sticky chromosome signifies high toxicity that could result in cell death. Bridged chromosomes could result from the general stickiness of the chromosomes at metaphase stage, or breakage and reunion of chromosomes (Chandel and Tank, 2016).

In this study, POME promoted root growth at $10 \%$ and yet induced the highest chromosomal aberrations at that same concentration. This probably implies that a particular wastewater may promote growth and still be genotoxic. Therefore, it is advisable that any wastewater that will be considered for farm irrigation should be tested for genotoxicity, even after treatments.

In a related study (Dada et al., 2018), POME generated by a corporate mill also had similar mitodepressive, cytotoxic, and genotoxic effects on the roots of $A$. cepa, but generally to a lower extent. Though, POME is inherently an environmental pollutant, the relatively higher pollutant loads in the present study, especially oil and grease, could be partly due to the fact that local palm oil millers do not subject their POME to any form of treatment (Okwute and Isu, 2007). Moreover, some of them do recycle POME which ought to be disposed of (Ohimain et al., 2012). These practices increase the tendency of local mill-generated POME to constitute pollution threat to the environment, ecological systems, and biodiversity. Since local milling generates a substantial quantity of palm oil consumed in Nigeria, and is a source of income and livelihood to many rural and town dwellers, their operations cannot be easily dispensed with. Therefore, for the safety of the environment, ecological systems, and biodiversity, it is imperative for the Nigerian governments and stakeholders to reach out to local millers with a view to discouraging them from reusing POME for palm oil milling. Reusing or recycling POME potentially increases retention of pollutants, including oil and grease. POME is naturally biodegradable, but the process is too slow to cope with the volumes generated. As such, local millers should also be encouraged to limit their operations to locations where there will be adequate spaces for the POME they generate to undergo natural biological degradation.

\section{Conclusions}

POME generated by a local mill was assessed in this study. The POME contained a very high concentration of oil and grease, in addition to other pollutants. The POME was also mitodepressive and cytotoxic, inducing various types of chromosomal aberrations. The observed low mitotic index, high mitotic inhibition, and aberrant chromosomes in the root cells of $A$. cepa likely resulted from the high pollutant loads in the POME. Although, the test was conducted on POME from one local mill, the results may be typical of many more local palm oil refineries who use mainly manual methods to extract oil from oil palm fruits. Local millers should be discouraged from reusing or recycling POME, and encouraged to limit their operations to locations where there will be adequate spaces for the POME they generate to undergo natural biological degradation.

\section{Authors' Contributions}

EOD designed the research and wrote the draft manuscript. OMG collected research samples and carried out laboratory analysis on the samples. MOS interpreted chromosomal data and took part in manuscript writing. HOI and OOA carried out statistical analysis and interpreted the data.

All authors read and approved the final manuscript. 


\section{Acknowledgements}

This research received no specific grant from any funding agency in the public, commercial, or not-forprofit sectors.

\section{Conflict of Interests}

The authors declare that there are no conflicts of interest related to this article.

\section{References}

Adegbite AE, Olorode O (2002). Karyotype studies of three species of Aspilia thouar (Heliantheae - Asteraceae) in Nigeria. Plant Science Research Communication 3:11-26.

American Public Health Association (APHA) (1998). American Standard Methods for Examinations of Water and Wastewater. 20 $0^{\text {th }}$ Ed. American Public Health Association (APHA)-American Water Works Association (AWWA)-American Pollution Control Federaation (WPCF), Washinghton, D. C.

Chandel M, Tank SK (2016). Cytogenetic study of Allium cepa root tip cells treated with textile effluent. Biotechnological Research 2(3):100-103.

Dada EO, Akinola MO, Haruna R (2018). Physico-chemical and genotoxicity assessments of palm oil mill effluent generated by a corporate refinery in Nigeria. Pollution 4(1):83-92. https://doi.org/10.22059/poll.2017.237168.293

Eze VC, Owunna ND, Avoaja DA (2013). Microbiological and physicochemical characteristics of soil receiving palm oil mill effluent in Umuahia, Abia State, Nigeria. Journal of Natural Sciences Research 3(7):163-169.

Fiskesjo G (1997). Allium test for screening chemicals: Evaluation of cytological parameters. Plant for Environmental Studies. 11:307-333. http://dx.doi.org/10.1201/9781420048711.ch11

Glinska S, Bartczak M, Oleksiaka S, Wolska A, Gabara B, Posmyk M (2007). Effects of anthocyanin-rich extract from red cabbage leaves on meristematic cells of Allium cepa L. roots treated with heavy metals. Ecotoxicological and Environmental Safety 68:343-350. https://doi.org/10.1016/j.ecoenv.2007.02.004

Igwe JC, Onyegbado CC (2007). A review of palm oil mill effluent (POME) water treatment. Global Journal of Environmental Research 1(2):54-62.

Kaymak F, Goc-Rasgele P (2009). Genotoxic effects of raxil on root tips and anthers of Allium cepa L. Caryologia 62(1):19. https://doi.org/10.1080/00087114.2004.10589659

Kwakaram IA (2016). Effects of fat, oil and grease (FOG) discharge pollutants on water quality of Qalyasan stream, Tanjero River and impact of of fat, oil and grease on Darbandikhan reservoir in Sulaimani City-Kurdistan Region of Iraq-Iraq. International Journal of Environment, Ecology, Family and Urban Studies 6(1):1-12.

Leme DM, Marin-Morales MA (2009). Allium cepa test in environmental monitoring: A review on its application. Mutation Research/Reviews in Mutation Research 682:71-81. https://doi.org/10.1016/j.mrrev.2009.06.002

Madaki YS, Seng L (2013). Palm oil mill effluent (POME) from Malaysia palm oil mills: waste or resource. International Journal of Science, Environment and Technology 2(6):1138-1155.

McPhail N (2015). Review of removal of fats, oil and greases from meat processing plants. A publication of Australian Meat Processor Corporation (AMPC), pp 26. https://silo.tips/download/review-of-removal-of-fats-oil-andgreases-from-effluents-from-meat-processing-pl

Ohimain EI, Seiyaboh EI, Izah SC, Oghenegueke EV, Perewarebo GT (2012). Some selected physico-chemical and heavy metal properties of palm oil mill effluents. Greener Journal of Physical Sciences 2(4):131-137. https://doi.org/10.1.1.1074.17518rep=rep1\&type $=p d f$

Okwute LO, Isu NR (2007). The environmental impact of palm oil mill effluent (POME) on some physico-chemical parameters and total aerobic bioload of soil atb a dump site in Anyigba, Kogi State, Nigeria. African Journal of Agricultural Research 2(12):656-662. 
Onyia CO, Uyu AM, Akunna JC, Norulaini NA, Omar AK (2001). Increasing the fertilizer value of palm oil mill sludge: bioaugmentation in nitrification. Water Science and Technology 44:157-162. https://doi.org/10.2166/wst.2001.0608

Orji MU, Nwokolo SO, Okoli I (2006). Effects of palm oil mill effluent on soil microflora. Nigerian Journal of Microbiology 20(2):1026-1031.

Otti VI, Ifeanyichukwu HI, Nwaorum FC, Ogbuagu FU (2014). Sustainable oil palm management in engineering development. Civil and Environmental Research 6(5):121-125.

Qian XW, Luo WH, Zheng OX (2006). Joint effects of microwave and chromium trioxide on root tip cells of Viciafaba. Journal Zhejiang University (Science) 7(3):221-227. https://doi.org/10.1631/jzus.2006.B0221

Radic S, Stipanicev D, Vujcic V, Rajcic MM, Sirac S, Pevalek-Kozlina B (2010). The evaluation of surface and wastewater genotoxicity using the Allium cepa test. Science of Total Environment 408:1228-1233. https://doi.org/10.1080/00087114.2004.10589659

Rupani PF, Singh RP, Ibrahim MH, Esa N (2010). Review of current palm oil mill effluent (POME) treatment methods: vermicomposting as a sustainable practice. World Applied Sciences Journal 11(1):70-81.

Sahu KR, Katiyar S, Tiwari J, Kisku CG (2007). Assessment of drain water receiving effluent from tanneries and its impact on soil and plants with particular emphasis on bioaccumulation of heavy metals. Journal of Environmental Biology 28(3):685-690.

Sudhakar R, Gowda KNN, Venu G (2001). Mitotic abnormalities induced by silk dyeing industry effluents in the cells of Allium cepa L. Cytologia 66:235-239. https://doi.org/10.30750/ijpbr.1.3.15

Thailand Department of Industrial Works, TDIW (1997). Environmental Management Guideline for the Palm Oil Industry. Thailand, PN 2000.2265.5-001.00, pp 75. https://www.elaw.org/system/files/th.palm.oil.industry.guidelines.pdf

Travis MJ, Weisbrod N, Gross A (2008). Accumulation of oil and grease in soils irrigated with grey water and their potential role in soil water repellency. Science of the Total Environment 394:68-74. https://doi.org/10.1016/j.scitotenv.2008.01.004
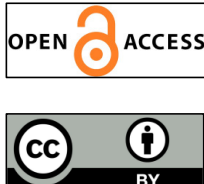

The journal offers free, immediate, and unrestricted access to peer-reviewed research and scholarly work. Users are allowed to read, download, copy, distribute, print, search, or link to the full texts of the articles, or use them for any other lawful purpose, without asking prior permission from the publisher or the author.

License - Articles published in Notulae Scientia Biologicae are Open-Access, distributed under the terms and conditions of the Creative Commons Attribution (CC BY 4.0) License.

(c) Articles by the authors; SHST, Cluj-Napoca, Romania. The journal allows the author(s) to hold the copyright/to retain publishing rights without restriction. 